\title{
Pradhan Mantri Jan-Dhan Yojana: An Evaluation
}

Ravikumar $\mathrm{T}^{*}$

\begin{abstract}
Financial inclusion is a process of providing access and usage of financial services like savings, credit, insurance and payment facilities by the financially excluded people. Initiatives towards financial Inclusion have been taken by the Government of India which includes priority lending, lead bank scheme, nationalisation of banks, Swabhimaan approach and Pradhan Mantri Jan Dhan Yojna (PMJDY). This article evaluates Pradhan Mantri Jan-Dhan Yojana scheme critically and its difference with a previous similar scheme.
\end{abstract}

Keywords: Pradhan Mantri Jan-Dhan Yojana, India, Financial Inclusion.

\section{Introduction}

In India, Financial Inclusion means the provision of financial services by the formal financial system to the excluded people at an affordable cost (Leeladhar, 2005).

The efforts to bring financially excluded people into formal financial services have started in 1947 (Rajan, 2009; Chakrabarty, 2011). The efforts include priority lending, lead bank scheme, nationalisation of banks, Swabhimaan approach and Pradhan Mantri Jan Dhan Yojna (PMJDY).

${ }^{*}$ CHRIST(Deemed to be University), Bengaluru, India;

ravikumar.t@christuniversity.in 
The swabhimaan scheme was introduced in the year 2011 by the Government of India (Chakrabarty, 2013). The scheme has successfully covered about 74,000 villages having more than 2,000 population with banking facilities. However, this scheme had few limitations such as access to digital money, accessing micro-credit and accessing micro-insurance. These limitations of Swabhimaan scheme were resolved through Pradhan Mantri Jan Dhan Yojna (PMJDY).

Pradhan Mantri Jan Dhan Yojna (PMJDY) was inaugurated on 15 August 2014 (Pradhan Mantri Jan Dhan Yojna, 2018). This scheme has the following missions:

- Access to finance through the formal financial system

- The opening of basic bank account and provision of Rupay card

- Increase financial literacy

- Credit guarantee fund

- Micro Insurance

- Provision of a pension scheme

\section{Objectives of the study and research methodology}

The primary objective of this study is to analyse the growth of Pradhan Mantri Jan-Dhan Yojana after its launch. This study is based on secondary data and is descriptive in nature.

\section{The approach of Pradhan Mantri Jan-Dhan Yojana}

In the year 2011, the Swabhimaan scheme successfully covered about 74,000 villages having more than 2,000 population with banking facilities. However, Swabhimaan scheme did not reach all financially exclude people and this scheme had limited impact (Department of Financial Services, 2018). Pradhan Mantri Jan-Dhan Yojana scheme takes the important learning of Swabhimaan approach and tends to provide a comprehensive approach towards financial inclusion in India.

Important points of differences between "Swabhimaan" and "Pradhan Mantri Jan-Dhan Yojana" are summarised in the following table. 
Table 1 Approaches of Swabhimaan and Pradhan Mantri Jan-Dhan Yojana

\begin{tabular}{|c|c|}
\hline Swabhimaan & Pradhan Mantri Jan-Dhan Yojana \\
\hline $\begin{array}{l}\text { It covers villages with } \\
\text { population greater than } \\
2000 \text { in rural areas }\end{array}$ & $\begin{array}{l}\text { It focuses on households both in rural and urban } \\
\text { areas. }\end{array}$ \\
\hline $\begin{array}{l}\text { The scheme insisted only } \\
\text { on account opening. So, } \\
\text { there were many dormant } \\
\text { accounts. }\end{array}$ & $\begin{array}{l}\text { This approach also insists on account opening and } \\
\text { but, the same account is seeded with Direct Benefit } \\
\text { Transfer, credit, insurance and pension. So, } \\
\text { accounts are vey much active. }\end{array}$ \\
\hline $\begin{array}{l}\text { Debit cards were provided } \\
\text { in some cases }\end{array}$ & RuPay Debit Card are provided \\
\hline $\begin{array}{l}\text { Mobile Banking facility was } \\
\text { not there }\end{array}$ & Mobile banking facility is available \\
\hline $\begin{array}{l}\text { KYC formalities were } \\
\text { lengthy and bulky }\end{array}$ & Simplified $\mathrm{KYC} / \mathrm{e}-\mathrm{KYC}$ is in place \\
\hline $\begin{array}{l}\text { No focus was given on } \\
\text { financial literacy }\end{array}$ & $\begin{array}{l}\text { Focus is given on financial literacy especially in } \\
\text { rural branches }\end{array}$ \\
\hline
\end{tabular}

\section{Achievements of Pradhan Mantri Jan-Dhan Yojana}

While launching, there was a target of enrolling over 7.5 crores (75 million) households in the scheme and to open their accounts. The target was very much achieved and in fact, the reality exceeded the target given. As on $1^{\text {st }}$ August 2018, the performance of Pradhan Mantri Jan Dhan Yojana is given below:

Table 2 Pradhan Mantri Jan Dhan Yojana

\begin{tabular}{|c|c|c|c|c|c|c|}
\hline $\begin{array}{l}\text { Bank } \\
\text { Type }\end{array}$ & $\begin{array}{c}\text { No. of } \\
\text { beneficiaries in } \\
\text { rural and semi- } \\
\text { urban area }\end{array}$ & $\begin{array}{c}\text { No. of } \\
\text { beneficiaries } \\
\text { in urban and } \\
\text { metro area }\end{array}$ & $\begin{array}{c}\text { No. of rural } \\
\text { and urban } \\
\text { female } \\
\text { beneficiaries }\end{array}$ & $\begin{array}{c}\text { Total } \\
\text { bene } \\
\text { ficiaries }\end{array}$ & $\begin{array}{l}\text { Deposits } \\
\text { in } \\
\text { accounts }\end{array}$ & $\begin{array}{c}\text { Number } \\
\text { of Rupay } \\
\text { cards } \\
\text { issued }\end{array}$ \\
\hline $\begin{array}{l}\text { Public } \\
\text { Sector } \\
\text { Banks }\end{array}$ & 14.02 & 12.03 & 13.52 & 26.05 & 64388.62 & 19.64 \\
\hline $\begin{array}{l}\text { Regional } \\
\text { Rural } \\
\text { Banks }\end{array}$ & 4.39 & 0.81 & 2.85 & 5.20 & 14072.06 & 3.70 \\
\hline $\begin{array}{l}\text { Private } \\
\text { Sector } \\
\text { Banks }\end{array}$ & 0.60 & 0.40 & 0.53 & 1.00 & 2214.15 & 0.93 \\
\hline $\begin{array}{l}\text { Grand } \\
\text { Total }\end{array}$ & 19.02 & 13.23 & 16.90 & 32.25 & 80674.82 & 24.27 \\
\hline
\end{tabular}

Source: PMJDY

Note: All figures are expressed in Crores 
From the above table, it can be observed that a total number of accounts opened under PMJDY scheme is 32.25 crores which is huge in size. Very importantly, these accounts have a total balance of around 80674 crores. Banks can exploit this opportunity of serving these people by providing suitable financial products and services. PMJDY has empowered 16.90 crores of females financially and they can now access and use formal financial products and services offered by the bankers. Further, PMJDY has issued 24.27 Rupay debit cards for the usage of banking services to the account holders. Rupay debit card is indigenous payment platform developed by National Payment Corporation of India. Rupay is similar to payment gateways like VISA, MASTER and so forth.

Further, PMJDY has extensively involved in providing financial awareness and financial education to the people. To create financial awareness and to provide financial education, PMJDY has started financial literacy skilling centres throughout India and those centres are performing well (Pradhan Mantri Jan Dhan Yojna, 2018). Moreover, PMJDY has 1.26 lakh Bank Mitras. Bank Mitra is a branchless banking service which provides banking services in subservice areas or areas where bank branches are not there.

\section{Challenges of Pradhan Mantri Jan-Dhan Yojana}

Although the PMJDY scheme performed well in a short period of time, it faces numerous challenges over a long period of time. First, sustaining this performance for a longer period could be one of the major challenges. Other challenges include the following:

1. Keeping the accounts "Live"

2. Creating awareness among people about financial inclusion and PMJDY scheme

3. Covering people from different social status and all areas of the country

4. Identifying appropriate technology to implement mobile financial inclusion 


\section{Conclusion}

"Pradhan Mantri Jan-Dhan Yojana" (PMJDY) has been one of the national policies which have been implemented rigorously. PMJDY concentrates on individuals in rural and urban areas rather than focusing on villages in rural areas. Over a period of time, the scheme has achieved more numbers in terms of account opening well before the target date of 31st January 2015 and even after 2015, the scheme is doing well in terms of account opening, and financial literacy skilling. The most important challenge is to sustain this performance over a period of time.

\section{References}

Chakrabarty, K. C. (November, 2011). Financial Inclusion: A road India needs to travel. RBI Bulletin. Retrieved from https:// www.rbi.org.in/scripts/BS_ViewBulletin.aspx?Id=12680

Chakrabarty, K. C. (2013). Financial Inclusion in India: journey so far and the way forward. Keynote address at Finance Inclusion Conclave organised by CNBC TV 18 at New Delhi. Retrieved from https:// www.bis.org/review/r130909c.pdf

Chakrabarty, K. C. (2013). Revving up the growth engine through financial inclusion. Address at the 32nd SKOCH Summit held at Mumbai. Retrieved from https://www.rbi.org.in/ scripts/ BS_ViewBulletin. aspx?Id=14282

Leeladhar, V. (2005). Taking banking services to the common man Financial Inclusion. Commemorative Lecture at the Fedbank Hormis Memorial Foundation at Ernakulam. Retrieved from https:// www.bis.org/ review/r051214e.pdf

Rajan, R. G. (2009). A hundred small steps - report of the committee on financial sector reforms. Retrieved from http:// planningcommission.nic.in/reports/genrep/rep_fr/cfsr_all.pdf

The Government of India. (n.d.). Pradhan Mantri Jan Dhan Yojana/Account Statistics. Retrieved from http://www.pmjdy.gov.in/account-statistics-country.aspx

The Government of India. (n.d.). Pradhan Mantri Jan Dhan Yojana/Skilling. Retrieved from https://pmjdy.gov.in/flc-skillingmaterial.aspx 